\title{
Maps and Genealogical Tables
}

Map I.I Northern Britain and Ireland c. 750

Map I.2 Northumbria and its principal churches 6

Map I.3 Dál Riata 8

Map I.I Scandinavia in the Viking age $\quad 48$

Map 2.I The wanderings of St Cuthbert's body in the late

Map 4.I Southumbria $\quad$ I59

Map 4.2 Æðelstan's campaign of $934 \quad$ I62

Map 4.3 Suggested locations for the battle of Brunanburh, 937 I70

Map 5.I The central transit zone of the Alpínid kingdom in the tenth and eleventh centuries 200

Map 6.I Gaelic Cenéla in the Alpínid kingdom $\quad \mathbf{2 2 8}$

Map 6.2 Anglo-Scottish relations c. Iо0о 237

Table I.I Some Northumbrian kings of the later eight century $\quad 4^{2}$

Table 6. I The Dál Riatan origins of the men of Alba 226

Table 6.2 The Moray dynasty 229

Table 6.3 Scandinavian kings of the early eleventh century 232

Table 6.4 Cumbrian kings of Strathclyde 238

Table 6.5 The descent of Gospatric son of Maldred 25I

Table 6.6 Congalach of Knowth and the kingship of Tara 257

$\begin{array}{ll}\text { Table 6.7 The relationship between Magnus Haraldsson of } & \\ & \text { Norway and Ingibjorg of Orkney }\end{array}$

Table 7.I Comparison of generation lengths in Viking Age dynasties 280

Table 7.2 The relationship of Thorsteinn to Sigurðr $\quad 284$

Table 7.3 Thorfinnr the Mighty and his kinsmen 309 